\title{
ARTICLE
}

\section{Fish Assemblages, Connectivity, and Habitat Rehabilitation in a Diked Great Lakes Coastal Wetland Complex}

\author{
Kurt P. Kowalski* \\ U.S. Geological Survey, Great Lakes Science Center, 1451 Green Road, Ann Arbor, Michigan 48105, USA
}

Michael J. Wiley

School of Natural Resources and Environment, University of Michigan, G504 Dana Building, 440 Church Street, Ann Arbor, Michigan 48109, USA

\author{
Douglas A. Wilcox \\ Department of Environmental Science and Biology, State University of New York-Brockport, \\ 350 New Campus Drive, Lennon Hall, Brockport, New York 14420, USA
}

\begin{abstract}
Fish and plant assemblages in the highly modified Crane Creek coastal wetland complex of Lake Erie were sampled to characterize their spatial and seasonal patterns and to examine the implications of the hydrologic connection of diked wetland units to Lake Erie. Fyke netting captured 52 species and an abundance of fish in the Lake Erie-connected wetlands, but fewer than half of those species and much lower numbers and total masses of fish were captured in diked wetland units. Although all wetland units were immediately adjacent to Lake Erie, there were also pronounced differences in water quality and wetland vegetation between the hydrologically isolated and lake-connected wetlands. Large seasonal variations in fish assemblage composition and biomass were observed in connected wetland units but not in disconnected units. Reestablishment of hydrologic connectivity in diked wetland units would allow coastal Lake Erie fish to use these vegetated habitats seasonally, although connectivity does appear to pose some risks, such as the expansion of invasive plants and localized reductions in water quality. Periodic isolation and drawdown of the diked units could still be used to mimic intermediate levels of disturbance and manage invasive wetland vegetation.
\end{abstract}

Great Lakes coastal wetlands provide valuable habitat for a large variety of both river- and lake-associated fish species (Herdendorf 1987; Jude and Pappas 1992; Wei et al. 2004; Larson et al. 2013). However, the ecological condition of river-mouth and lacustrine wetlands in the Great Lakes region has declined significantly since intensive human development in the coastal zone and upland landscapes began to accelerate over a century ago (Campbell and Gavin 1995). This is particularly true of western Lake Erie, where changes in water quality and extensive hydrologic modifications have affected contributing watersheds, the wetlands themselves, and the coastal lake environs they border.

The Glacial Lake Plain of northwestern Ohio once supported a large area of coastal wetlands that comprised the eastern edge of the Great Black Swamp (Kaatz 1955). However, more than $96 \%$ of the wetland habitats along the U.S. shoreline of Lake Erie have been lost since the 1860s (Herdendorf 1987; Mitsch and Wang 2000), and most of the remaining wetlands along the shore have been isolated hydrologically by earthen dikes to protect them from wave attack and to promote

*Corresponding author: kkowalski@usgs.gov

Received October 1, 2013; accepted March 5, 2014 
intensive management as migratory bird habitat. In fact, diked wetlands constitute the majority of holdings managed by state and federal refuge systems in the western basin of Lake Erie; for instance, diked units comprise approximately $80 \%$ of the U.S. Fish and Wildlife Service's (USFWS) Ottawa National Wildlife Refuge (ONWR). Water levels in diked coastal units generally are controlled directly by managers to promote the growth of wetland plants, inhibit the growth of invasive species, reduce high turbidity, and provide optimal habitat structure for waterfowl, shorebirds, and muskrats Ondatra zibethicus (Gray et al. 2013). Although these diked units lie adjacent to the Lake Erie shoreline, they do not provide many of the ecological functions typical of coastal wetlands (e.g., migratory fish habitat and fluvial nutrient and sediment retention), and often they are not classified as coastal wetlands due to their hydrologic isolation from the lake and coastal tributaries (Keough et al. 1999; Albert et al. 2005; Simon and Stewart 2006).

Hydrologic connection to Lake Erie does not necessarily ensure that coastal wetlands will provide quality habitat for fishes and other aquatic biota. Intensive land development for urban and agricultural uses has severely degraded the ecological condition of most Lake Erie tributary systems (Herdendorf 1987; Kowalski and Wilcox 1999; Kasat 2006; Riseng et al. 2010). Although undiked wetlands remain hydrologically connected to the lake, their water quality is often severely degraded by nutrients, sediment export, and other contaminants (Maynard and Wilcox 1997). Additional factors, including the presence of invasive species, the alteration of watershed hydrology, and the armoring of banks and adjacent Lake Erie shorelines, have also contributed to the severe degradation of the few remaining undiked wetlands in this region (Herdendorf 1987; Maynard and Wilcox 1997; Kowalski and Wilcox 1999).

At a time when efforts to rehabilitate the degraded coastal habitats of the Great Lakes are attracting unprecedented national investment (Great Lakes Restoration Initiative 2010), the need for careful, science-based evaluation and prioritization of restoration activities has never been greater. Lake Erie coastal wetlands undoubtedly require extensive water quality rehabilitation and hydrologic rehabilitation. However, important questions arise concerning the relationship between fish habitat quality and hydrologic isolation, both in terms of the direct impact on accessibility to fishes and the indirect impacts on the wetland plant communities with which they are associated. Is there any ecological benefit in reconnection if water quality remains poor or is made worse? Are there any ecological trade-offs, such that potential gains in biological function from restored connectivity are offset by potential losses caused by reconnection to degraded upland habitat (e.g., potential expansion of invasive plant species)? Given the potential risks, what relative priority should we place on hydrologic reconnection as a component of coastal wetland rehabilitation?

Our study began to address these issues by examining fish and plant assemblages in Lake Erie-connected wetland units and adjacent diked wetland units located within the USFWS ONWR. We documented seasonal patterns of biological composition and abundance in isolated diked wetland units and lake-connected units with varying degrees of water quality impairment and proximity to Lake Erie. Specifically, our objectives were to (1) identify differences in fish species richness, abundance, and composition between the poorer-water quality but hydrologically connected coastal wetland units and the managed diked units; (2) characterize differences in plant community quality and extent in relation to the connectivity and water quality of the wetland units; and (3) consider the implications of reconnecting the diked wetlands in terms of fish habitat restoration.

\section{STUDY SITE}

We studied four sites within the Crane Creek drowned-rivermouth wetland complex, which is managed by the USFWS ONWR $\left(41^{\circ} 37^{\prime} 42.999^{\prime \prime} \mathrm{N}, 83^{\circ} 12^{\prime} 28.0008^{\prime \prime} \mathrm{W}\right)$ and is located along the southern shore of western Lake Erie, approximately $48 \mathrm{~km}$ southeast of Toledo, Ohio (Figure 1). Crane Creek flows into the over 370-ha wetland complex from the west and exits to Lake Erie through a permanent channel between a break in shoreline dikes on the eastern boundary. Bounding earthen dikes that were built in the early 1900s constrict the channel and its floodplain wetlands beginning at a point approximately $1.7 \mathrm{~km}$ upstream from the junction with Lake Erie, thus dividing the connected drowned-river-mouth wetland into the upper and lower marsh wetland units: Crane Creek upper (CCUp; 210 ha) and Crane Creek lower (CCLow; 160 ha).

As with many other drowned-river-mouth wetlands, waterlevel fluctuations in Lake Erie drive the water levels in the hydrologically connected coastal units (Keough et al. 1999). Annual water levels in Lake Erie can fluctuate greatly ( $>1 \mathrm{~m}$ ) depending on antecedent climate. Short-term, wind-initiated water-level oscillations (i.e., seiches) also occur, often with an amplitude between 0.7 and $2.0 \mathrm{~m}$, and can exceed $3.0 \mathrm{~m}$ during major storm events (Herdendorf 1987). Thus, water depth in these units varies over time but was less than $1 \mathrm{~m}$ in most areas of the wetland during the present study. Large nutrient loads from agricultural and point-source discharges in the watershed contribute to poor water quality in CCUp and CCLow and in their connecting channel with Lake Erie (Kasat 2006; Robertson and Saad 2011).

Earthen levees and rock revetment comprise most of the unit boundaries, but robust emergent wetland plants (e.g., narrowleaf cattail Typha angustifolia and common reed Phragmites australis) populate the perimeter of the marsh, while floating-leaf assemblages of American lotus Nelumbo lutea and longleaf pondweed Potamogeton nodosus extend further from shore. Deep, silty sediments, often with abundant seed banks (Barry et al. 2004), cover most of the wetland except in a few areas where greater water velocities expose sand and a hard-clay-pan bottom (Bowers 2003). 

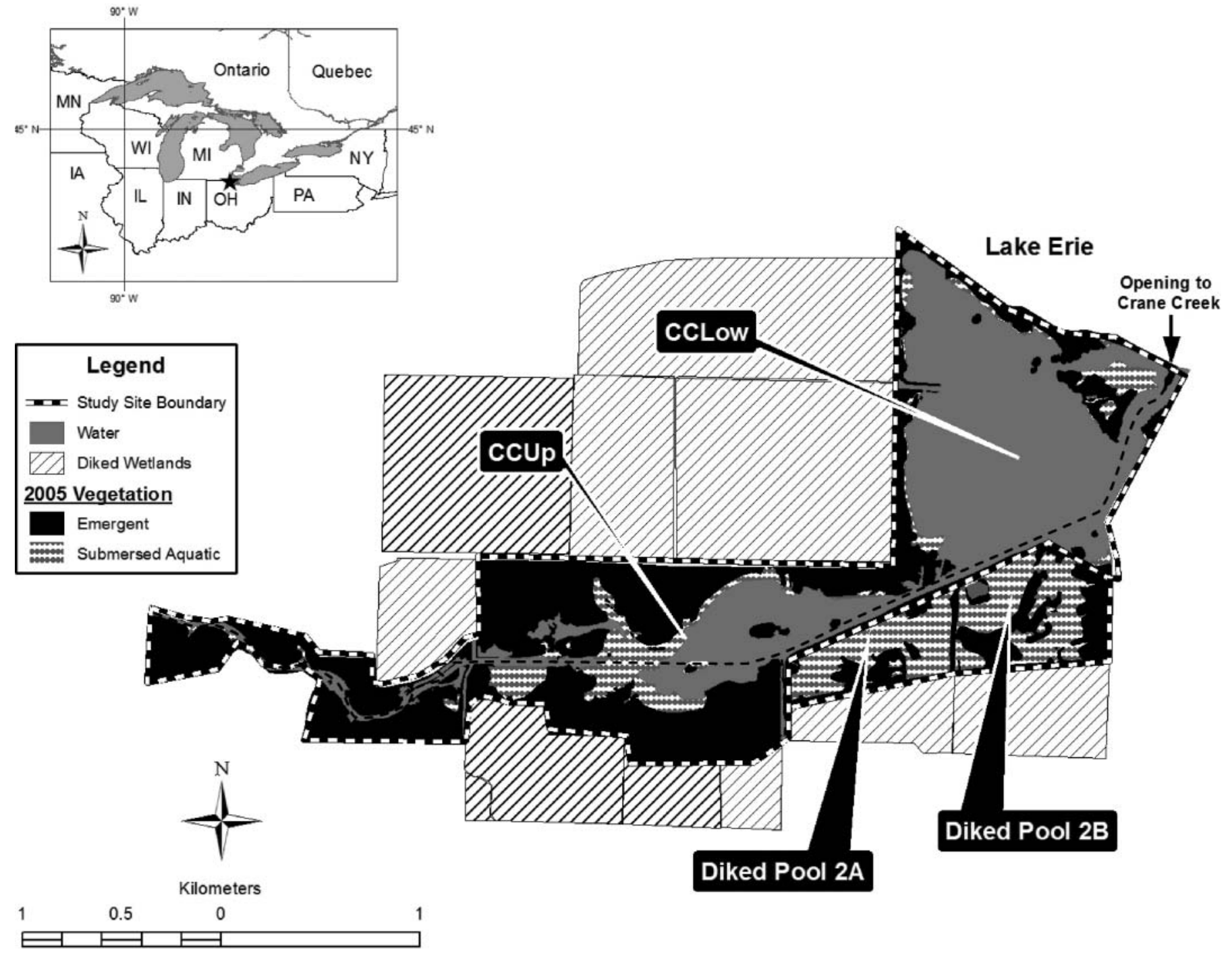

FIGURE 1. Location of the Crane Creek wetland complex adjacent to western Lake Erie. Emergent and submersed aquatic vegetation is noted for lake-connected wetland sites (CCUp and CCLow) and isolated diked wetland units (pools 2A and 2B).

Diked wetland units were located immediately adjacent to Crane Creek (see Figure 1) on former coastal marshland. Pools 2A (28 ha) and 2B (40 ha) are diked units that have been hydrologically isolated from Crane Creek since the 1940s except during a few major flood events (e.g., 1973). Diesel pumps are used to move water into or out of the pools to achieve specific management objectives (e.g., provide periodic shallow-water shorebird habitat or initiate a seed bank response), but precipitation and evapotranspiration can also affect the water level in these units. During the study, water depths generally were less than $1 \mathrm{~m}$ except in a few former borrow pits, where water depths exceeded $3 \mathrm{~m}$.

\section{METHODS}

Field sampling.-We used winged fyke nets to sample the fish assemblages quantitatively. Nets in small frames $(45 \times$
$45 \mathrm{~cm})$ and large frames $(91 \times 91 \mathrm{~cm})$ and with each of two knotted mesh sizes $($ small $=0.48 \mathrm{~cm}$; large $=1.27 \mathrm{~cm}$ ) were set at haphazardly determined locations within each of the four sites to capture both large and small fish. For each sample within each site, we set eight fyke nets in 24-h sets for two consecutive days during the spring (April-June), summer (July-August), and fall (November) of 2004 and 2005. The four large-frame nets were set facing the shore in water depths of $1 \mathrm{~m}$ or greater, with 6-15-m-long leads perpendicular to and reaching shore and 3-m-long wings extending to each side. The four small-frame nets were set similarly in water that was less than $1 \mathrm{~m}$ deep. All nets were set with leads extending into the edge of dominant emergent vegetation (e.g., narrowleaf cattail or American lotus) when present at sampling locations. Data from the CCLow, CCUp, Pool 2A, and Pool 2B sites were analyzed individually. Catch data from all nets were combined for each site, averaged over the 
number of nets yielding data (e.g., 16 nets), and expressed as CPUE (fish/net-day).

Fish were identified, counted, measured (TL; nearest $\mathrm{mm}$ ), and released unless preserved for further taxonomic work. If the number of individuals exceeded 100 for a given species, then only a 100-fish subsample was measured for TL, and the remaining fish were enumerated only. Biomass of each species was estimated using formulas given by Schneider et al. (2000).

Plant community analyses. - To characterize the fish habitat provided by wetland vegetation, we used aerial photo interpretation and quantitative sampling of major vegetation associations (per Kowalski and Wilcox 1999). Color infrared aerial photographs at nominal scales of 1:8,000 and 1:24,000 were collected during July 2005, and major vegetation types that were clearly definable on the photographs were groundtruthed in the field. Preparation of aerial photos for stereo interpretation with a mirror stereoscope was completed via the procedures outlined by Owens and Hop (1995). We identified, delineated, digitized, and georeferenced the boundaries of major wetland vegetation associations in the study areas.

The composition of major vegetation associations was characterized quantitatively to identify differences in fish habitat between lake-connected wetland sites and diked wetland sites. Wetland plants were sampled during August 2004 and 2005 by using up to twenty $1-\times 1-\mathrm{m}$ quadrats placed haphazardly in each dominant wetland vegetation association that was identifiable in aerial photographs. Visual estimation was used to assign a percent cover value to all identifiable plant species. Herbaceous plant nomenclature followed that of eFloras (2009), and tree nomenclature followed that given by Gleason and Cronquist (1991). Plant species richness and species importance values (sum of relative frequency and relative mean cover; Curtis and McIntosh 1951) were calculated for each site to characterize potential fish habitat.

Water quality analyses.-Monthly water grab samples were collected at CCUp, Pool 2A, and Pool 2B during MayNovember 2004 and April-June 2005 and were analyzed for total soluble reactive phosphorus (SRP), ammonia-N, and nitrite-N/nitrate-N by using standard methods (Kasat 2006). At CCLow, water quality characteristics (i.e., dissolved oxygen $[\mathrm{DO}], \mathrm{mg} / \mathrm{L}$; temperature, ${ }^{\circ} \mathrm{C}$; turbidity, $\mathrm{NTU}$; and $\mathrm{pH}$, measured using $\mathrm{H}$ ion concentrations) were recorded at 10min intervals from May 5 to October 24, 2005, by using a YSI Model 6920 sonde (YSI, Yellow Springs, Ohio). Water quality conditions in Pool 2B were not monitored continuously in 2005, although periodic spot measurements were made with a comparable sonde. To estimate the frequency of oxygen stress in the diked units, we obtained hourly measurements that were collected using a YSI Model 6920V2 sonde in Pool 2B from June 23 to September 15, 2009 (J. Eash, USFWS, unpublished data). These data were consistent with but more complete than the 2005 spot measurements (K. P. Kowalski and K. Huffman, USFWS, unpublished data). The interquartile range method was used to remove outliers (i.e., greater than three times the interquartile range above the third quartile or below the first quartile) from all logged data.

Data analyses. - General linear model nested factorial design ANOVAs with Scheffé's post hoc multiple comparisons were used to test for differences between years, among seasons, between connectivity types, and among sites (Data Desk software, Data Description, Ithaca, New York). Preliminary analyses made it clear that there were no significant differences between 2004 and 2005, so our basic model explored the effects of connectivity (connected = yes or no), season (spring, summer, or fall), site (see Figure 1), and the interactions of these factors. Sites were nested in the treatment factor (CCUp and CCLow in connected $=$ yes; pools $2 \mathrm{~A}$ and $2 \mathrm{~B}$ in connected $=$ no). To prepare for multivariate analysis and to account for the high variance of species in each sample, the biomass data were $\log$ transformed (McCune and Grace 2002). Species that were found at three or fewer of the sites were not included in the multivariate analyses (McCune and Grace 2002). To reduce data dimensionality, PC-ORD version 5.27 was used to perform a nonmetric multidimensional scaling of the abundance data (autopilot mode set to "slow and thorough," Euclidean distance measure, random starting number, 500 runs with real data, 500 runs with randomized data, and 500 maximum iterations). The Bray-Curtis dissimilarity metric (values from 0 to 1 ) was used to describe differences in fish and plant community composition (Bray and Curtis 1957). Smaller values indicate greater similarity in species composition.

\section{RESULTS}

\section{Fish}

Abundance and diversity.-We collected a total of 126,381 fish over 267 net-days of effort (see Supplementary Table S.1 in the online version of this article). Average abundance in the diked unit samples was significantly lower (Tables 1,2$)$ than that in the connected Crane Creek units (CPUE $=42$ and 684 fish/net-day, respectively). Likewise, mean catch biomass was nearly five times higher in the hydrologically connected marsh units $(14 \mathrm{~kg} / \mathrm{net}$-day) than in the diked units $(3 \mathrm{~kg} / \mathrm{net}$-day). Of the 52 fish species identified from these wetland samples, all occurred in the hydrologically connected Crane Creek units, whereas 25 occurred in the diked units. Mean sample species richness was almost three times greater $(P<0.001)$ in the connected units ( 28.8 species captured/net-day) than in the diked units (11.6 species captured/net-day). Significant seasonal differences were found in total biomass but not in numerical abundance or species richness (Table 1). Biomass was greatest in spring samples and decreased through the summer and fall (Table 2). There were relatively small but statistically significant site-specific differences. Post hoc comparisons indicated that CCLow (closest connected unit to Lake Erie) had significantly greater fish densities and species richness than the other units. 
TABLE 1. Results of general linear model balanced factorial design ANOVAs for abundance, biomass, and species richness (2004 and 2005 combined) in sampled Crane Creek wetland units. Data were analyzed by season, treatment (lake connected versus isolated), and site. Significant $(P<0.05)$ values are in bold italics.

\begin{tabular}{llcc}
\hline Metric & Season & Treatment (connectivity) & Site \\
\hline Abundance & 0.5371 & $\mathbf{0 . 0 0 0 3}$ & $\mathbf{0 . 0 3 0 7}$ \\
Biomass & $\mathbf{0 . 0 0 0 4}$ & $\mathbf{0 . 0 0 0 1}$ & $\mathbf{0 . 0 2 5 7}$ \\
Species richness & 0.524 & $\mathbf{0 . 0 0 0 1}$ & $\mathbf{0 . 0 5 4 6}$ \\
\hline
\end{tabular}

In the Crane Creek marsh units, the Emerald Shiner Notropis atherinoides was the most numerically abundant species, followed by the Gizzard Shad Dorosoma cepedianum, Tadpole Madtom Noturus gyrinus, and Bluegill Lepomis macrochirus. The Common Carp Cyprinus carpio, Bowfin Amia calva, Smallmouth Buffalo Ictiobus bubalus, and Gizzard Shad dominated sample biomass in CCLow and CCUp. In the disconnected pools, the Bluegill was the most numerically abundant fish taxon, followed by the Largemouth Bass Micropterus salmoides, Green Sunfish Lepomis cyanellus, and Yellow Bullhead Ameiurus natalis. The Bowfin, Common Carp, Northern Pike Esox lucius, and Yellow Bullhead comprised most of the biomass in the diked units.

Community composition.-The composition of the fish assemblage varied dramatically in relation to connectivity; for the Crane Creek marsh units, the assemblage composition also varied by season. In nonmetric multidimensional scaling ordination space, the seasonal variability and spatial variability in species composition of the connected unit samples were striking (Figure 2), as was the relative lack of variability in the composition of the diked units. Axis 1 reflected a gradient (Table S.2) from centrarchid and typical floodplain species (e.g., Bluegill, Green Sunfish, and Largemouth Bass) toward a more diverse cyprinid and Great Lakes-related assemblage (e.g., Alewife Alosa pseudoharengus, Spotfin Shiner Cyprinella spiloptera, Round Goby Neogobius melanostomus, and Freshwater Drum Aplodinotus grunniens). Axis 2 captured seasonal shifts in dominant species, with spring sample

TABLE 2. Fish species richness, mean abundance (CPUE $=$ fish/net-day), and mean biomass (kg/net-day) for each season ( $\mathrm{Sp}=$ spring; $\mathrm{Su}=$ summer; $\mathrm{Fa}=$ fall) during 2004 and 2005 sampling in the Lake Erie-connected Crane Creek wetland units (CCUp and CCLow) and in the adjacent diked pools (pools 2A and 2B).

\begin{tabular}{|c|c|c|c|c|c|c|c|c|c|}
\hline \multirow[b]{2}{*}{ Site } & \multicolumn{3}{|c|}{ Richness } & \multicolumn{3}{|c|}{ Abundance } & \multicolumn{3}{|c|}{ Biomass } \\
\hline & $\mathrm{Sp}$ & $\mathrm{Su}$ & $\mathrm{Fa}$ & Sp & $\mathrm{Su}$ & $\mathrm{Fa}$ & Sp & $\mathrm{Su}$ & $\mathrm{Fa}$ \\
\hline CCUp & 33 & 33 & 34 & 534.6 & 254.8 & 432.5 & 26.7 & 17.7 & 5.1 \\
\hline CCLow & 41 & 42 & 35 & 824.7 & 703.9 & $1,348.4$ & 20.0 & 8.2 & 4.0 \\
\hline Pool 2A & 19 & 17 & 15 & 12.3 & 133.6 & 33.5 & 1.9 & 2.5 & 2.4 \\
\hline Pool 2B & 11 & 13 & 11 & 35.7 & 20.3 & 14.7 & 3.8 & 1.7 & 4.2 \\
\hline
\end{tabular}

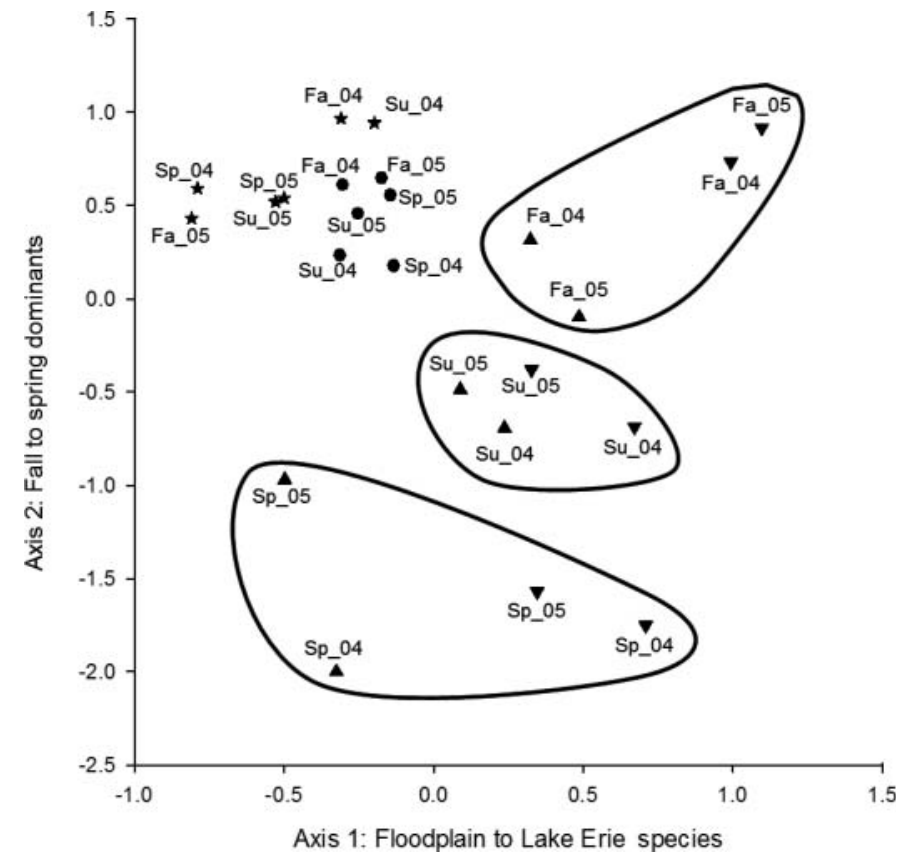

FIGURE 2. Nonmetric multidimensional scaling ordination of fyke-net samples in species composition space. Note the wide seasonal and intersite variation of connected versus isolated wetland unit samples (circles $=$ Pool 2A samples; stars $=$ Pool 2B samples; upward triangles $[\mathbf{\Delta}]=$ Crane Creek upper samples; downward triangles $[\boldsymbol{\nabla}]=$ Crane Creek lower samples). Sample code indicates season $(\mathrm{Sp}=$ spring; $\mathrm{Su}=$ summer; $\mathrm{Fa}=$ fall $)$ and sample year $(04=2004 ; 05=2005)$. Final three-dimensional solution stress was 3.56620 after 237 iterations.

composition being more distinct than the summer and fall composition in connected Crane Creek units. Little seasonal variability was evident in the diked unit samples.

All of the fish species found in pools $2 \mathrm{~A}$ and $2 \mathrm{~B}$ also were found at CCLow. However, only $48 \%$ of the fish species captured at CCUp or CCLow were found in either Pool 2A or Pool 2B. Some taxa were only found at one site (e.g., Silver Chub Macrhybopsis storeriana, Golden Shiner Notemigonus crysoleucas, and Silverjaw Minnow Notropis buccatus at CCLow), but most were found at more than one site. The Smallmouth Bass Micropterus dolomieu was the only species that was found in Pool 2A or Pool 2B but not at CCUp. Eight species that were captured in CCLow were not also captured in CCUp, but only the Silverjaw Minnow was unique to the CCUp site. Species composition of the two diked pools was more similar between the pools than to either of the Crane Creek sites (Bray-Curtis dissimilarity $=0.50$ ), with the greatest dissimilarity observed between Pool 2A and CCLow (Bray-Curtis dissimilarity $=0.99$ ).

Some differences between seasonality of the abundance and biomass data clearly reflected spawning behaviors and changes in age structure over the three seasons (Figure 3). For example, over $67 \%$ of Gizzard Shad captured in the Lake Erie-connected sites during spring were adults (TL > $30.5 \mathrm{~cm}$; Trautman 1981). Later in the year, however, we 

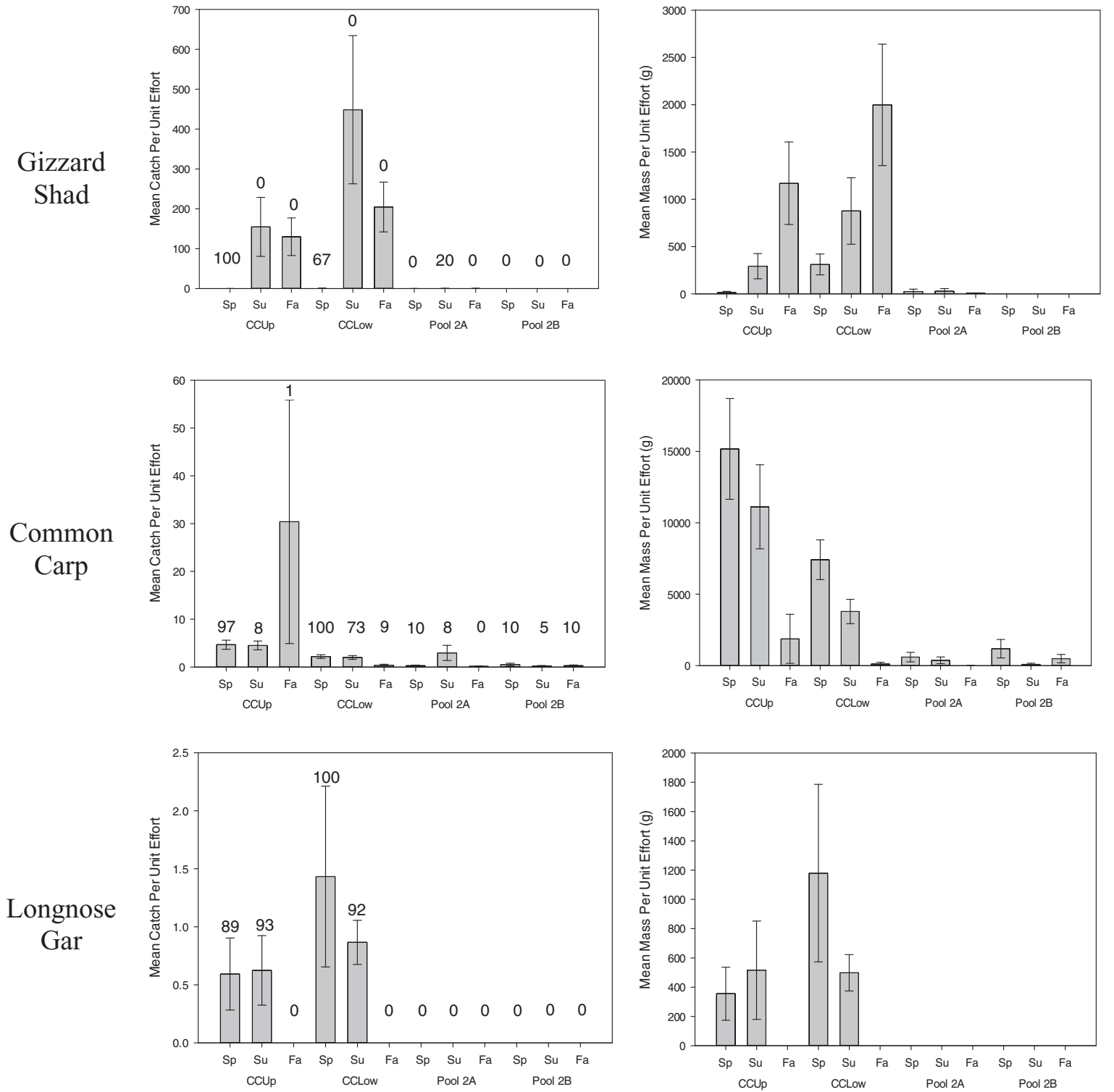

FIGURE 3. Seasonal patterns of abundance (CPUE $=$ fish/net-day) and biomass (g/net-day) for three representative fish species (Gizzard Shad, Common Carp, and Longnose Gar) in the Lake Erie-connected Crane Creek wetland units (CCUp and CCLow) and in the adjacent diked pools (pools 2A and 2B). Error bars represent a single SE; 2004 and 2005 data are combined ( $\mathrm{Sp}=$ spring; Su = summer; Fa = fall). Percentages of captured fish that were adult length (Trautman 1981) are noted above the bars.

found only age-0 and juvenile Gizzard Shad with a mean TL of $5.7 \mathrm{~cm}$ (CCLow) in summer and $9.5 \mathrm{~cm}$ in fall, the season when Gizzard Shad biomass was the highest (Figure 3). Gizzard Shad were rare or absent in pools 2A and 2B.

Likewise, large numbers of Common Carp were caught in the spring. Individuals captured during spring were almost exclusively adults, whereas less than $10 \%$ of the Common Carp captured in the Crane Creek units during the fall were adult length (TL $\geq 30.5 \mathrm{~cm}$; Trautman 1981). Total Common Carp biomass also was lowest during the fall $(P<0.0031)$ at connected sites. Although numbers were much lower, adult Common Carp dominated the catch in Pool 2B during both the spring and the fall. In contrast, Longnose Gar Lepisosteus osseus using the wetlands were almost exclusively adults, and they persisted in relatively high numbers from spring through the summer sampling period. There was, however, little 
indication of age-0 Longnose Gar production, and this species disappeared entirely from the fall samples, suggesting that Longnose Gars used the wetland for foraging rather than for reproduction.

\section{Plants}

Emergent wetland vegetation and submersed aquatic vegetation (SAV) accessible by fish were present in all units (Table 3), but the composition of the plant assemblages varied. The Bray-Curtis analysis indicated that the diked pools were more similar in community composition to each other than to the Crane Creek units, and likewise the plant communities of the Crane Creek units were more similar to each other than to the plant communities of the diked pools. Pool 2B was the most dissimilar to both of the lake-connected units: BrayCurtis dissimilarity was 0.84 for CCLow and 0.79 for CCUp.

In the Crane Creek units, 209.6 ha (or $54.8 \%$ of the total area) were vegetated, with most (176.7 ha) located in the CCUp site (84.1\% of that site's area). Forty-six plant taxa were observed in CCUp (52 taxa when CCLow was included), and the greatest importance values were calculated for emergent species, including the broadleaf arrowhead Sagittaria latifolia (31.8), common reed (31.2), narrowleaf cattail (22.9), American lotus (18.3), and needle spikerush Eleocharis acicularis (14.8). Fifty percent of the plant taxa were forbs, and four commonly invasive taxa were present (flowering rush Butomus umbellatus, reed canarygrass Phalaris arundinacea, common reed, and narrowleaf cattail).

The CCLow site supported 32.9 ha of vegetation (i.e., $20.6 \%$ of the site's area), which was mostly located adjacent to the shore, on islands, or in small, isolated patches. Nine of the 17 plant taxa found at the CCLow site were SAV species, while only three taxa were classified as forbs. American lotus and the invasive common reed had the greatest importance values ( 41.5 and 41.5 , respectively), and the invasive narrowleaf cattail had the next-largest importance value (29.7). Several SAV species also had high importance values.

Based on interpretation of aerial photographs, 71.0 ha (98.2\%) of the diked wetlands were covered by woody plants, herbaceous plants, or SAV. The Pool 2A site had the greatest plant species richness (50 species), although Pool 2B (48 species) also had greater richness than the CCLow and CCUp sites. Forbs were the most frequently found plant type in both pools. Approximately $24 \%$ of the species in Pool 2A were SAV, with another $24 \%$ belonging to the grasses, sedges, or rushes category. Pool 2B supported a greater percentage of SAV plants (29\%) than Pool 2A, yet only eight grass, sedge, or rush species were found in Pool 2B (17\% of the total). The same two invasive plant species (i.e., flowering rush and narrowleaf cattail) were present in both pools, but unlike the Lake Erie-connected units, no other invasive plant species were observed in the samples. Although water knotweed Polygonum amphibium primarily dominated Pool 2B (importance
TABLE 3. Calculated importance values for the plant species sampled in the Crane Creek upper (CCUp), Crane Creek lower (CCLow), Pool 2A, and Pool 2B wetland sites. Plant species richness at each site is noted in the final row.

\begin{tabular}{|c|c|c|c|c|}
\hline \multirow[b]{2}{*}{ Species } & \multicolumn{4}{|c|}{ Site } \\
\hline & CCUp & CCLow & $\begin{array}{c}\text { Pool } \\
2 \mathrm{~A}\end{array}$ & $\begin{array}{c}\text { Pool } \\
\text { 2B }\end{array}$ \\
\hline & Forbs & & & \\
\hline Abutilon theophrasti & 0.33 & & 0.42 & 0.50 \\
\hline Alisma triviale & 0.34 & & 2.68 & 1.02 \\
\hline Ammannia robusta & 6.61 & & & \\
\hline Asclepias incarnata & & & 0.42 & 1.52 \\
\hline Azolla caroliniana & & & & 6.09 \\
\hline Bidens cеrnиа & 1.83 & & 1.40 & 4.40 \\
\hline Bidens connata & 0.34 & & & 0.47 \\
\hline Bidens frondosa & & & & 0.47 \\
\hline Bidens sp. & 1.11 & & 4.77 & \\
\hline Boehmeria cylindrica & & & & 0.92 \\
\hline Cicuta bulbifera & & & & 2.33 \\
\hline Cirsium arvense & & & 0.42 & \\
\hline Decodon verticillatus & & & & 1.68 \\
\hline Echinocystis lobata & 0.33 & & & \\
\hline Euthamia graminifolia & & & 1.68 & \\
\hline Galium trifidum & 1.01 & & & 0.50 \\
\hline Hibiscus moscheutos & 0.36 & & & 0.90 \\
\hline Impatiens capensis & 0.98 & & & \\
\hline Lindernia dubia & 2.18 & & & \\
\hline Ludwigia palustris & 3.08 & & 0.57 & \\
\hline Lycopus uniflorus & 0.67 & & & 3.20 \\
\hline Lythrum salicaria & & 1.38 & & \\
\hline Malva moschata & & & 0.42 & \\
\hline Melilotus alba & & & 0.42 & \\
\hline Mimulus ringens & 1.40 & & 3.01 & \\
\hline $\begin{array}{l}\text { Mosses (general, non- } \\
\text { Sphagnum) }\end{array}$ & & & & 1.04 \\
\hline Nelumbo lutea & 18.25 & 41.54 & 19.61 & \\
\hline Nymphaea odorata & & & 0.45 & 2.40 \\
\hline Penthorum sedoides & & & 1.55 & 0.95 \\
\hline Polygonum amphibium & & & 22.25 & 39.58 \\
\hline $\begin{array}{l}\text { Polygonum } \\
\quad \text { hydropiperoides }\end{array}$ & 0.40 & & & \\
\hline Polygonum persicaria & 0.64 & & 0.87 & \\
\hline Polygonum punctatum & 0.69 & & & \\
\hline Ranunculus flabellaris & & & 1.31 & 0.45 \\
\hline Rorippa islandica & 0.39 & & & \\
\hline Rotala ramosior & 0.79 & & 2.32 & \\
\hline Sagittaria latifolia & 31.79 & 10.41 & 0.42 & 1.97 \\
\hline Sagittaria sp. & & & 0.42 & \\
\hline Saururus cernuиs & 1.59 & & & \\
\hline Scirpus cyperinus & & & & 0.45 \\
\hline Scutellaria galeri & & & 0.45 & \\
\hline
\end{tabular}

(Continued on next page) 
TABLE 3. Continued.

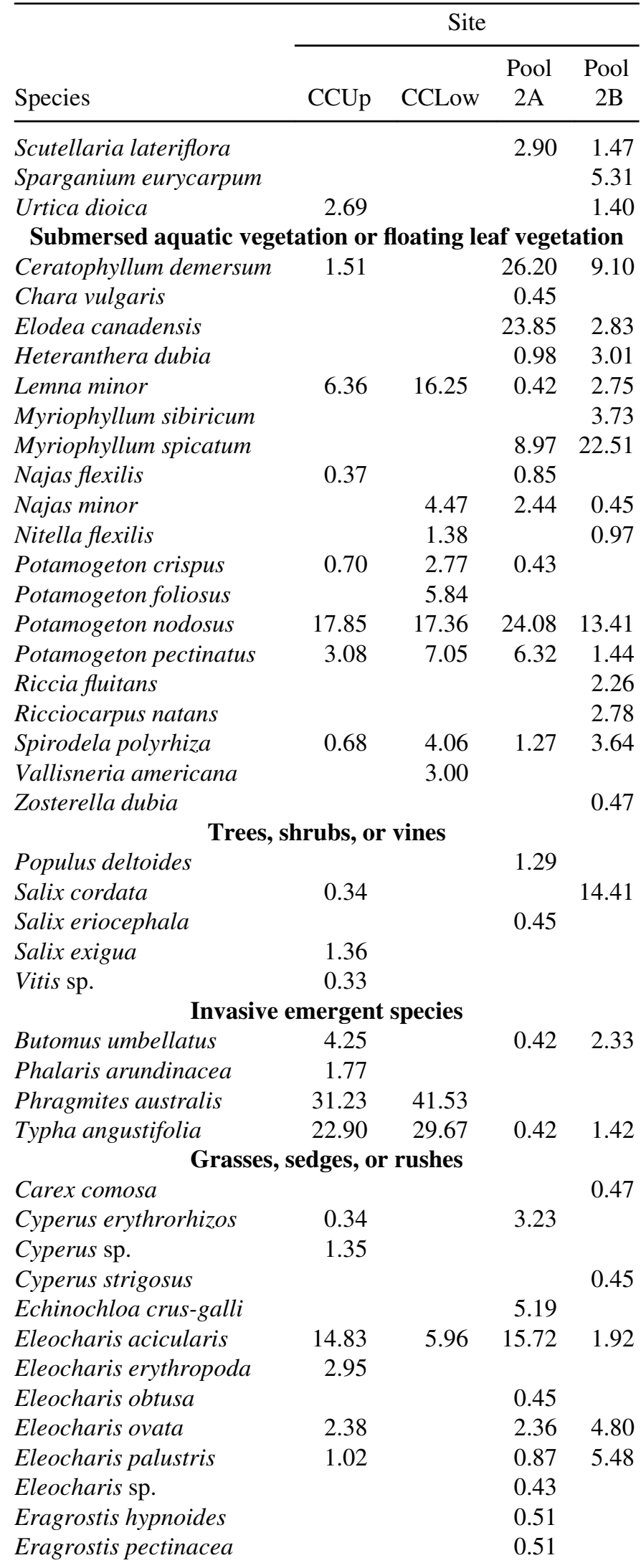

TABLE 3. Continued.

\begin{tabular}{lcccc}
\hline & \multicolumn{5}{c}{ Site } \\
\cline { 2 - 5 } & CCUp & CCLow & 2A & 2B \\
\hline Species & 0.33 & & & \\
\hline Juncus nodosus & 3.55 & 1.42 & 1.82 & 17.47 \\
Leersia oryzoides & & & 0.42 & \\
$\begin{array}{l}\text { Panicum capillare } \\
\text { Schoenoplectus } \\
\quad \text { tabernaemontani }\end{array}$ & & 1.42 & 0.87 & 0.61 \\
$\begin{array}{l}\text { Scirpus fluviatilis } \\
\text { Species richness }\end{array}$ & 1.39 & & & \\
\hline
\end{tabular}

value $=39.6$ ), Pool $2 \mathrm{~A}$ supported a more robust SAV or floating leaf assemblage composed of coon's tail Ceratophyllum demersum (26.2), longleaf pondweed (24.1), and Canadian waterweed Elodea canadensis (23.9).

\section{Water Quality}

Crane Creek water flowing into the refuge wetlands had elevated conductivity and nutrient concentrations (characteristic of agricultural areas on the Erie Lake Plain), especially in comparison with water flowing from the refuge wetland complex to Lake Erie or water in the diked pools. Nitrate-N concentrations in Crane Creek at the ONWR boundary ranged from 0.02 to $3.19 \mathrm{mg} / \mathrm{L}$, with lower values associated with warm summer flows that were stalled by Lake Erie seiche elevations and accompanying anoxia. Conductivity ranged from 106 to $1,004 \mu \mathrm{S} / \mathrm{cm}$, and SRP ranged from 0.01 to $0.23 \mathrm{mg} / \mathrm{L}$. In the CCUp wetland, nitrate-N concentrations ranged up to $1 \mathrm{mg} / \mathrm{L}$ (mean $=0.18 \mathrm{mg} / \mathrm{L})$ and were higher than those in CCLow (maximum $=0.26 \mathrm{mg} / \mathrm{L}$; mean $=0.09 \mathrm{mg} / \mathrm{L}$ ), as were SRP concentrations $(0.01-0.03 \mathrm{mg} / \mathrm{L})$ and conductivities (106-614 $\mu \mathrm{S} / \mathrm{cm})$. Water quality in the diked pools was even better, with maximum values (observed in either pool) of $0.12 \mathrm{mg} / \mathrm{L}$ for nitrate- $\mathrm{N}$ and $0.06 \mathrm{mg} / \mathrm{L}$ for SRP. Conductivity in the pools ranged from 200 to $627 \mu \mathrm{S} / \mathrm{cm}$.

Continuous monitoring by sonde suggested that important differences in turbidity and oxygen availability also existed between the Lake Erie-connected Crane Creek marsh units and the diked sites (Table 4). At the CCLow sonde, turbidity averaged 59.4 NTU during the sampling period (minimum = 22.3 NTU; maximum $=127.5 \mathrm{NTU}$ ). Average daily DO ranged from 5.6 to $15.2 \mathrm{mg} / \mathrm{L}$ during the summer growing season. Hypoxic conditions (i.e., DO $<3 \mathrm{mg} / \mathrm{L}$; generally nighttime measurements) were observed on $9 \%$ of the days, and DO levels less than $4 \mathrm{mg} / \mathrm{L}$ occurred on $21 \%$ of the days.

In Pool 2B, temperature conditions were generally similar to those observed at the CCLow site. However, the daily mean turbidity in Pool 2B was lower (19.4 NTU; minimum $=0.1$ $\mathrm{NTU}$; maximum $=71.6 \mathrm{NTU})$, and the daily mean DO ranged 
TABLE 4. Summary statistics for water quality data collected at the Crane Creek lower site (CCLow; May 5-October 24, 2005) and the diked wetland site Pool 2B (June 23-September 15, 2009; Pool 2B data are courtesy of Josh Eash, U.S. Fish and Wildlife Service).

\begin{tabular}{|c|c|c|c|c|c|c|c|c|}
\hline Variable & $\begin{array}{c}\text { Min } \\
\text { daily mean }\end{array}$ & $\begin{array}{c}\text { Max } \\
\text { daily mean }\end{array}$ & $\begin{array}{l}\text { Daily } \\
\text { mean }\end{array}$ & SD & $\begin{array}{c}\text { Max } \\
\text { daily range }\end{array}$ & $\begin{array}{l}\text { Date of } \\
\text { max range }\end{array}$ & $\begin{array}{c}\% \text { days DO } \\
<3 \mathrm{mg} / \mathrm{L}\end{array}$ & $\begin{array}{l}\% \text { days DO } \\
<4 \mathrm{mg} / \mathrm{L}\end{array}$ \\
\hline \multicolumn{9}{|c|}{ CCLow, 2005} \\
\hline Temperature $\left({ }^{\circ} \mathrm{C}\right)$ & 9.9 & 29.8 & 22.1 & 4.9 & 11.7 & Oct 1 & & \\
\hline DO (mg/L) & 5.6 & 15.2 & 9.3 & 1.8 & 16.6 & Oct 4 & 9.0 & 21.2 \\
\hline Stage $(\mathrm{m})$ & 174.1 & 174.4 & 174.2 & 0.1 & 0.6 & Aug 31 & & \\
\hline $\mathrm{pH}$ & 7.9 & 9.2 & 8.6 & 0.2 & 2.4 & Oct 18 & & \\
\hline Turbidity (NTU) & 22.3 & 127.5 & 59.4 & 21.7 & 221.3 & May 11 & & \\
\hline \multicolumn{9}{|c|}{ Pool 2B, 2009} \\
\hline Temperature $\left({ }^{\circ} \mathrm{C}\right)$ & 18.6 & 33.2 & 23.9 & 2.0 & 6.7 & Sep 13 & & \\
\hline DO (mg/L) & 0.5 & 12.5 & 5.8 & 1.3 & 10.4 & Sep 8 & 48.2 & 74.1 \\
\hline Stage (m) & 174.0 & 174.6 & 174.4 & 0.1 & 0.4 & Aug 29 & & \\
\hline $\mathrm{pH}$ & 7.6 & 9.5 & 8.5 & 0.4 & 1.6 & Aug 8 & & \\
\hline Turbidity (NTU) & 0.1 & 71.6 & 19.4 & 8.6 & 65.9 & Sep 4 & & \\
\hline
\end{tabular}

from 0.5 to $12.5 \mathrm{mg} / \mathrm{L}$, with a daily mean of $5.8 \mathrm{mg} / \mathrm{L}$. Hypoxic conditions in Pool 2B occurred more frequently during the summer, with over $48 \%$ of the days having DO levels less than $3 \mathrm{mg} / \mathrm{L}$; DO less than $4 \mathrm{mg} / \mathrm{L}$ occurred on $74 \%$ of the days. This difference in oxygen stress for Pool 2B was apparently related to the nighttime respiration demands of the extensive SAV.

\section{DISCUSSION}

Despite the generally poorer water quality delivered by Crane Creek to its river-mouth wetlands, utilization of CCLow and CCUp by fishes was greater than the utilization of diked pools, and productivity in the free-flowing units significantly and greatly exceeded that in the adjacent diked wetland units. Despite acknowledged difficulties in reducing nutrient and sediment loads from Lake Erie watersheds, it seems that hydrologic reconnection of these and similar diked wetland units could be a relatively easy means to bolster coastal Lake Erie fish populations. Differences between fish assemblages in coastal and diked wetlands have been noted for many years (Johnson 1989; Johnson et al. 1997; Markham et al. 1997; Bouvier 2006), but this study demonstrated that (1) many fishes access even degraded Lake Erie coastal wetland habitats (e.g., those with poor water quality and invasive plant species) throughout the year; (2) there are large seasonal variations in patterns of utilization by many fishes; and (3) there may also be ecological risks involved with hydrologic reconnection, including increased nutrient loading and turbidity, reduced SAV coverage in connected coastal marshes, and increased facilitation of invasive plants.

\section{Dynamic Use of Lake-Connected Wetlands by Fishes}

Unlike the adjacent isolated diked units, the lake-connected Crane Creek wetland supported a diverse suite of fishes and was a very productive environment, with a high yet seasonally variable biomass of fish. At least 52 fish species were using CCUp and CCLow even though water quality conditions were relatively poor (Kasat 2006) and the few vegetated areas were dominated by a limited suite of plant species. Compared with previous studies of fishes using Lake Erie coastal marshes, our results suggest that these habitats continue to be highly productive and ecologically valuable even after decades of degradation (Johnson 1989; Jude and Pappas 1992; Maynard and Wilcox 1997; Kowalski and Wilcox 1999; Riseng et al. 2010). A number of the species we observed to use the marshes are important components of the open-water fishery in Lake Erie; for example, White Bass Morone chrysops, Channel Catfish Ictalurus punctatus, Smallmouth Bass, and Silver Chub are recreationally or commercially harvested (Herdendorf 1987; Nepszy 1999). The lake-connected habitats were also used by several listed species or species of concern in Michigan, Ohio, and/or Ontario, Canada (e.g., Sand Shiner Notropis stramineus, Black Buffalo Ictiobus niger, Silver Shiner Notropis photogenis, and Western Banded Killifish Fundulus diaphanus menona). The widespread use of these habitats by important prey species (e.g., Gizzard Shad, Emerald Shiner, and Spottail Shiner Notropis hudsonius) is consistent with earlier observations by others (Mansfield 1984; Chubb and Liston 1986; Lapointe 1986; Stephenson 1990; Jude and Pappas 1992; Wei et al. 2004; Bouvier 2006; Bouvier et al. 2009) and reinforces the idea that even Lake Erie coastal marshes with degraded conditions (e.g., marshes that are present yet limited in extent and composition) are useful to coastal fish communities. These abundant forage species, in addition to age- 0 fish of all species, not only provide food for larger local predatory species in the wetlands (e.g., Longnose Gar, Northern Pike, and Largemouth Bass; Scott and Crossman 1998) but also for the many piscivorous waterbirds (e.g., bald eagle Haliaeetus leucocephalus, great egret Ardea alba, and great blue heron Ardea 
herodias) that are found in large numbers at the Crane Creek unit of the ONWR (Martin 2000).

Observed seasonal variability in hydrologically connected wetland fish assemblages and biomass is related to many factors, including changing water quality, species reproductive strategies, and other life history traits, and may also reflect some sampling biases related to water level (Jude and Papas 1992; Scott and Crossman 1998). For example, although summer was generally the period when the fewest fish were caught during our study, a few species were numerically abundant during the summer months (e.g., Channel Catfish, Gizzard Shad, White Bass, and White Crappie Pomoxis annularis). Obviously, the inaccessibility of adjacent diked wetland habitats prevented their use by the same suite of fish, even though those pools could have provided habitats dominated by a more diverse and extensive assemblage of wetland plants than would be found in the lake-connected sites. Reproductively mature fish appeared to be using the Crane Creek marsh habitats mostly in the spring, likely for purposes of finding suitable spawning conditions (e.g., warmer water, egg attachment sites, and protection from predators). For example, during the spring, $100 \%$ of the Gizzard Shad captured at the CCUp site and nearly $67 \%$ of those captured at the CCLow site were large enough to be considered adults (Trautman 1981). It is likely that these fish were there to spawn or were feeding in the productive shallows before spawning in Lake Erie nearshore areas. By summer, large shoals of young Gizzard Shad were using the wetland as a nursery even though the water temperature was quite warm and there were large diurnal swings in DO level (K. P. Kowalski, personal observation). Lower catch biomass for these fishes during the summer may reflect both smaller size and reduced fyke-net capture efficiency for age-0 fish. Lower overall abundance of Gizzard Shad in the fall was probably attributable to age-0 mortality and the emigration of all size-classes to Lake Erie.

Even if a temporary hydrologic connection had existed in the spring (due to overdike flooding or pump-entrained passage), the diked wetlands would have made relatively poor nursery areas because the fish would have been unable to emigrate to better habitat when DO levels and/or water levels fell during the warm summer months (Johnson 1989). Overnight DO levels reached problematically low levels (e.g., $<3 \mathrm{mg} /$ L). Both connected and isolated study units experienced these seasonal stresses, although they were more severe in the diked units. Fishes in the lake-connected units had accessible refugia in Lake Erie, and diel migrations to and from the marshes were observed with a dual-frequency identification sonar at the mouth of Crane Creek (K. P. Kowalski, personal observation). However, fishes in the diked wetlands are trapped there, and lower summer and fall biomass levels probably represented mortality. Finally, as pointed out by Johnson (1989), whatever recruitment does occur in the diked units has little relevance to coastal Lake Erie population dynamics since those fishes are retained in the diked units.
Some species, such as the Common Carp, had seasonally declining catches in the connected units, with their lowest biomass levels occurring in the fall. Adults that were observed in the spring tended to leave the marsh after spawning and appeared not to return - a movement pattern that was previously noted by Jude and Pappas (1992) and Penne and Pierce (2008). Although some managers have expressed concern that opening diked wetlands to access by fish might lead to increased wetland damage by mature Common Carp (e.g., uprooted vegetation and higher turbidity from feeding; K. P. Kowalski, personal observation), disturbance should decrease after the spawning season if the mature Common Carp are allowed to leave. Other, less-destructive fish (e.g., Longnose Gars) followed similar seasonal patterns, as they accessed the connected wetland habitats only in the spring and summer, with a retreat to Lake Erie at other times of the year.

Only small fish are able to enter and exit the diked wetlands, and then only via the pumps that are used to move water to or from Crane Creek-a period of, at most, several days per year. Presumably, large fish are excluded from the pools completely. These conditions support the development of fish assemblages in the diked pools that are distinct but not unique in comparison with the fish assemblages found in the lake-connected CCUp and CCLow sites (Table S.1). All 25 of the fish species that were found in pools $2 \mathrm{~A}$ and $2 \mathrm{~B}$ were also found at the Crane Creek sites, suggesting that the fish species in the diked wetlands constitute just a pumped-in subset of the greater source populations in Crane Creek and Lake Erie. The most abundant fishes in the Crane Creek wetland assemblage (e.g., Gizzard Shad and Emerald Shiner) were probably a larger component of the diked wetland assemblage after the last major breach of the earthen dikes in the early 1970s. However, once the isolation of the diked wetlands was re-established, the long-term survival of these fish was unlikely because of harsh environmental conditions, predation, or periodic drawdown. Nighttime DO minima, for example, were generally even lower in the diked units than in Crane Creek proper. Dissolved oxygen dropped low enough to create hypoxic conditions in the deepest section of Pool 2B on more than $48 \%$ of the days in which we collected samples. Many species may have been extirpated by the low-DO conditions, but they also may have been outcompeted by species that are better adapted to the shallow lentic habitat (e.g., the Common Carp, Black Bullhead Ameiurus melas, Bluegill, and Largemouth Bass). The large diversity of plant species and structural forms (i.e., habitat complexity) in the diked wetlands provided extensive habitat for centrarchids, thus potentially promoting increased fish diversity (Emery 1978) even without the presence of lake-associated species. Johnson et al. (1997) observed similar conditions in other Lake Erie wetlands and also concluded that the diked wetland fish communities were isolated and distinct from other nearby populations. More specifically, an analysis of the size and age of White Crappies also suggested that diked wetland populations were functionally 
isolated from those in coastal wetlands despite occasional water exchange (Markham et al. 1997).

\section{Implications for Habitat Rehabilitation}

Wetland management actions (e.g., exotic species removal and periodic dewatering) commonly aim to promote the growth of emergent vegetation and to maximize food and habitat for shorebirds, ducks, and other migratory waterbirds (Gray et al. 2013). Historically, little consideration has been given to improving habitat for fishes, although it is commonly presumed that plant community diversity is beneficial to wetland fishes (Scott and Crossman 1998; Mitsch and Gosselink 2007). Although not always supporting greater plant species richness, the resulting plant assemblages are often reported to be robust and well established in comparison with nearby coastal wetlands that have been degraded by poor water quality, extended periods of high water levels, or shoreline armoring (Sherman et al. 1996; Gottgens et al. 1998; Thiet 2002). However, isolation from the fluctuating water levels in Lake Erie prevents these diked habitats from maintaining diverse plant assemblages without the regular management drawdown actions that mimic lake-driven events.

Management of water levels and control of invasive plant species (e.g., common reed and purple loosestrife Lythrum salicaria) by refuge managers over the previous 35 years have undoubtedly contributed to woody, herbaceous, and aquatic vegetation covering over 99\% of Pool 2A and 98\% of Pool 2B (Martin 2000). These plant assemblages were quite similar to each other, yet very different from those of the degraded CCLow site, which supported a much lower plant species richness but much higher fish abundance and fish species richness. Surprisingly, the CCUp site was similar in plant species richness to pools 2A and 2B even though CCUp was exposed to many of the stressors (e.g., Common Carp access, shoreline armoring, and high nutrient loads) that degraded the CCLow site. The greater plant species richness in CCUp was probably associated with the suite of species growing in the higher-elevation wet meadows and transitional mudflats on the margins of that unit, but the higher level of plant species richness did not translate into increased fish habitat usage relative to CCLow. Similarly, the diverse and extensive plant-rich habitats of the diked pools did not translate into increased habitat for fishes compared with the more degraded but connected wetland units.

The results of this and related studies suggest that maintaining and enhancing hydrologic connectivity are vital to the rehabilitation of fish habitat in Lake Erie coastal wetlands. If permanent hydrologic reconnection can restore access to vegetated fish habitat but leads to some ecological degradation of the wetland plant community, are there options to minimize that impact? Wilcox and Whillans (1999) suggested that mimicry of natural processes (e.g., hydrology) is a good rehabilitation philosophy, so we argue that careful management intervention can be used to mimic natural hydrologic fluctuations while still maximizing the seasonal use of wetlands by Lake Erie fishes. Some authors (e.g., Rogers et al. 1994) have suggested that only opening fish passage or water-control structures at certain times of the year could reduce the negative impacts of an impoundment while still excluding problematic species. However true this may be, we suggest that anything less than full hydrologic connection throughout the entire year will impact the Lake Erie fish assemblages negatively, as our results show that many different coastal fishes use wetland habitats at different times and for different purposes. Access to valuable coastal wetland habitat could be restored by using an appropriately designed fish passage structure that allows fish of most shapes and sizes to pass through while periodically excluding larger invasive species like the Common Carp (French et al. 1999). Gated or other structures that can be closed temporarily also could facilitate infrequent management actions that may require isolation of an area (e.g., dewatering an area to stimulate a seed bank [Kowalski et al. 2009] or to remove invasive wetland vegetation) to achieve broader habitat management objectives.

\section{ACKNOWLEDGMENTS}

Financial support from the U.S. Environmental Protection Agency's Great Lakes National Program Office allowed the research team from the U.S. Geological Survey (USGS) Great Lakes Science Center and University of Michigan School of Natural Resources and Environment (SNRE) to complete this project. We are grateful to USFWS ONWR managers Dan Frisk and Doug Brewer for their permission to access refuge properties during this project, and we thank their staff for continued assistance with field data collection. We appreciated the help of USGS staff and the many students at SNRE, including Matt Ladewig, Solomon David, Yu-Chun Kao, and Sarah Friedl, who assisted with field work and data analysis. Finally, we thank the known and anonymous reviewers for their constructive comments. Any use of trade, product, or firm names is for descriptive purposes only and does not imply endorsement by the U.S. Government. This article is Contribution 1827 of the USGS Great Lakes Science Center.

\section{REFERENCES}

Albert, D. A., D. A. Wilcox, J. W. Ingram, and T. A. Thompson. 2005. Hydrogeomorphic classification for Great Lakes coastal wetlands. Journal of Great Lakes Research 31(Supplement 1):129-146.

Barry, M. J., R. Bowers, and F. A. De Szalay. 2004. Effects of hydrology, herbivory and sediment disturbance on plant recruitment in a Lake Erie coastal wetlands. American Midland Naturalist 151:217-232.

Bouvier, L. D. 2006. The effects of aquatic connectivity on the distribution and abundance of fishes in wetlands of the lower Great Lakes. Master's thesis. University of Guelph, Guelph, Ontario. 
Bouvier, L. D., K. Cottenie, and S. E. Doka. 2009. Aquatic connectivity and fish metacommunities in wetlands of the lower Great Lakes. Canadian Journal of Fisheries and Aquatic Sciences 66:933-948.

Bowers, R. 2003. Interactions between unionids and zebra mussels in a Lake Erie coastal wetland. Master's thesis. Kent State University, Kent, Ohio.

Bray, J. R., and J. T. Curtis. 1957. An ordination of the upland forest communities in southern Wisconsin. Ecological Monographs 27:325-349.

Campbell, L. W., and C. Gavin. 1995. The marshes of southwestern Lake Erie. Ohio University Press, Athens.

Chubb, S. L., and C. R. Liston. 1986. Density and distribution of larval fishes in Pentwater Marsh, a coastal wetland on Lake Michigan. Journal of Great Lakes Research 12:332-343.

Curtis, J. T., and R. P. McIntosh. 1951. An upland forest continuum in the prairie-forest border region of Wisconsin. Ecology 32:476-496.

eFloras. 2009. Missouri Botanical Garden, St. Louis, and Harvard University Herbaria, Cambridge, Massachusetts. Available: http://www.efloras.org. (October 2009).

Emery, A. R. 1978. The basis of fish community structure: marine and freshwater comparisons. Environmental Biology of Fishes 3:33-47.

French, J. R. P. III, D. A. Wilcox, and S. J. Nichols. 1999. Passing of Northern Pike and Common Carp through experimental barriers designed for use in wetland restoration. Wetlands 19:883-888.

Gleason, J. A., and A. Cronquist. 1991. Manual of vascular plants of northeastern United States and adjacent Canada, 2nd edition. New York Botanical Garden Press, Bronx, New York.

Gottgens, J. F., B. P. Swartz, R. W. Kroll, and M. Eboch. 1998. Longterm GIS-based records of habitat changes in a Lake Erie coastal marsh. Wetlands Ecology and Management 6:5-17.

Gray, M. J., H. M. Hagy, J. A. Nyman, and J. D. Stafford. 2013. Management of wetlands for wildlife. Pages $121-180$ in J. T. Anderson and C. A. Davis, editors. Wetland techniques, volume 3. Springer, Secaucus, New Jersey.

Great Lakes Restoration Initiative. 2010. Great Lakes Restoration Initiative action plan. Available: http://greatlakes_restoration.us/ pdfs/glri_actionplan.pdf. (June 2014).

Herdendorf, C. E. 1987. The ecology of the coastal marshes of western Lake Erie: a community profile. U.S. Fish and Wildlife Service Biological Report 85(7.9).

Johnson, D. L. 1989. Lake Erie wetlands: fisheries considerations. Pages 257-273 in K. A. Krieger, editor. Lake Erie estuarine systems: issues, resources, status, and management. National Oceanic and Atmospheric Administration, Washington, D.C.

Johnson, D. L., W. E. Lynch, and T. W. Morrison. 1997. Fish communities in a diked Lake Erie wetland and an adjacent undiked area. Wetlands 17:43-54.

Jude, D. J., and J. Pappas. 1992. Fish utilization of Great Lakes coastal wetlands. Journal of Great Lakes Research 18:651-672.

Kaatz, M. R. 1955. The Black Swamp: a study in historical geography. Annals of the Association of American Geographers 45:1-35.

Kasat, R. J. 2006. Nutrient dynamics in a small agricultural Lake Erie tributary. Master's thesis. University of Michigan, Ann Arbor.

Keough, J. R., T. A. Thompson, G. R. Guntenspergen, and D. A. Wilcox. 1999. Hydrogeomorphic factors and ecosystem responses in coastal wetlands of the Great Lakes. Wetlands 19:821-834.
Kowalski, K. P., and D. A. Wilcox. 1999. Use of historical and geospatial data to guide the restoration of a Lake Erie coastal marsh. Wetlands 19:858-868.

Kowalski, K. P., D. A. Wilcox, and M. J. Wiley. 2009. Stimulating a Great Lakes coastal wetland seed bank using portable cofferdams: implications for habitat rehabilitation. Journal of Great Lakes Research 35:206-214.

Lapointe, G. D. 1986. Fish movement and predation on macroinvertebrates in a lakeshore marsh. Master's thesis. University of Minnesota, Minneapolis.

Larson, J. H., A. S. Trebitz, A. D. Steinman, M. J. Wiley, M. C. Mazur, V. Pebbles, H. A. Braun, and P. W. Seelbach. 2013. Great Lakes rivermouth ecosystems: scientific synthesis and management implications. Journal of Great Lakes Research 39:513-524.

Mansfield, P. J. 1984. Reproduction by Lake Michigan fishes in a tributary stream. Transactions of the American Fisheries Society 113:231-237.

Markham, C. A., W. E. Lynch Jr., D. L. Johnson, and R. W. Petering. 1997. Comparison of White Crappie populations in diked and undiked Lake Erie. Ohio Journal of Science 97: 72-77.

Martin, L. D. 2000. Ottawa National Wildlife Refuge, comprehensive conservation plan. U.S. Fish and Wildlife Service, Bloomington, Minnesota.

Maynard, L., and D. Wilcox. 1997. Coastal wetlands. State of the Lakes Ecosystem Conference 1996. U.S. Environmental Protection Agency, EPA 905-R-97-015b, Washington, D.C. and Environment Canada, En40-11/35-2-1997E, Ottawa.

McCune, B., and J. B. Grace. 2002. Analysis of ecological communities. MjM Software, Gleneden Beach, Oregon.

Mitsch, W. J., and J. G. Gosselink. 2007. Wetlands, 4th edition. Wiley, Hoboken, New Jersey.

Mitsch, W. J., and N. Wang. 2000. Large-scale coastal wetland restoration on the Laurentian Great Lakes: determining the potential for water quality improvement. Ecological Engineering 15:267282.

Nepszy, S. J. 1999. The changing fishery in Lake Erie. Pages 233-239 in M. Munawar, T. Edsall, and I. F. Munawar, editors. State of Lake Erie past, present and future. Backhuys Publishers, Leiden, The Netherlands.

Owens, T., and K. D. Hop. 1995. Long-term resource monitoring program standard operating procedures: field station photointerpretation. National Biological Service, Environmental Management Technical Center, LTRMP 95-P008-2, Onalaska, Wisconsin.

Penne, C. R., and C. L. Pierce. 2008. Seasonal distribution, aggregation, and habitat selection of Common Carp in Clear Lake, Iowa. Transactions of the American Fisheries Society 137:1050-1062.

Riseng, C. M., M. J. Wiley, P. W. Seelbach, and R. J. Stevenson. 2010. An ecological assessment of Great Lakes tributaries in the Michigan Peninsulas. Journal of Great Lakes Research 36:505-519.

Robertson, D. M., and D. A. Saad. 2011. Nutrient inputs to the Laurentian Great Lakes by source and watershed estimated using SPARROW watershed models. Journal of American Water Resources Association 47:1011-1033.

Rogers, D. R., B. D. Rogers, and W. H. Herke. 1994. Structural marsh management effects on coastal fishes and crustaceans. Environmental Management 18:351-369.

Schneider, J. C., P. W. Laarman, and H. Gowing. 2000. Lengthweight relationships. Chapter 17 in J. C. Schneider, editor. 
Manual of fisheries survey methods II: with periodic updates. Michigan Department of Natural Resources, Fisheries Special Report 25, Ann Arbor.

Scott, W. B., and E. J. Crossman. 1998. Freshwater fishes of Canada. Galt House Publications, Oakville, Ontario.

Sherman, D. E., R. W. Kroll, and T. L. Engle. 1996. Flora of a diked and an undiked southwestern Lake Erie wetland. Ohio Journal of Science 96:4-8.

Simon, T. P., and P. M. Stewart. 2006. Introduction: coastal wetlands of the Laurentian Great Lakes and the development of indicators of condition. Pages 3-16 in T. P. Simon and P. M. Stewart, editors. Coastal wetlands of the Laurentian Great Lakes: health, habitat, and indicators. AuthorHouse, Bloomington, Indiana.
Stephenson, T. D. 1990. Fish reproductive utilization of coastal marshes of Lake Ontario near Toronto. Journal of Great Lakes Research 16:71-81.

Thiet, R. K. 2002. Diversity comparisons between diked and undiked coastal freshwater marshes on Lake Erie during a high-water year. Journal of Great Lakes Research 28:285-298.

Trautman, M. B. 1981. The fishes of Ohio. Ohio State University Press, Columbus.

Wei, A., P. Chow-Fraser, and D. Albert. 2004. Influence of shoreline features on fish distribution in the Laurentian Great Lakes. Canadian Journal of Fisheries and Aquatic Sciences 61:1113-1123.

Wilcox, D. A., and T. H. Whillans. 1999. Techniques for restoration of disturbed coastal wetlands of the Great Lakes. Wetlands 19:858-868. 